\title{
MAPPING SPACE IN FICTION OF ANDREI PLATONOV
}

\section{Keba O. V.}

\section{INTRODUCTION}

The specificity of space is the fundamental problem of A. Platonov's poetics. Scholars have been trying to investigate and describe correlation between real social and geographical space (as well historical time) and their fictional forms in the writer's works. Spatiality as a special category of Platonov's prose has been studied repeatedly. Plot motifs and visual images associated with space attracted the attention of literary critics, cultural experts, and philosophers: The greatest interest among works of this direction are studies of Yu. Levin ${ }^{1}$, V. Podoroga ${ }^{2}$, as well detailed comments on the Chevengur of Ye. Yablokov ${ }^{3}$. Geographical images of the novel Chevengur have been considered by D. Zamyatin ${ }^{4}$. It also seems promising to consider the spatial aspects of the writer's work in the context of the so-called "magic realism". One of the most important features of this style is a "magical space", which "although it can be quite specifically delineated, does not completely coincide with any real geographical and historical space, since the space of magical realism does not obey the generally accepted forms of determinism, but lives according to its own magical - laws..."5

The aim of the research is to identify the different aspects of spatiality in Platonov's fiction: "space of life" (the relation between the real sociohistorical space and the fictional one), and "space of text" (specific language of modeling of text and a system of relations between textual elements based on substitution of sequence in time on simultaneity in space).

1 Левин Ю. От синтаксиса к смыслу и далее («Котлован» А. Платонова). Семиотика и информатика. Вып. 30. Москва, 1990. С. 115-148.

2 Подорога В. Евнух души. Позиция чтения и мир Платонова. Параллели (Россия Восток - Запад). Альманах философской компаративистики. Вып. 2. Москва, 1991. C. 33-82.

3 Яблоков Е. А. На берегу неба (роман Андрея Платонова «Чевенгур»). Санкт.Петербург : Изд-во «Буланин», 2001. 376 с.

4 Замятин Д.Н. Империя пространства: географические образы в романе А. Платонова «Чевенгур» Филологические науки. 2000. № 1. С. 14-23.

${ }^{5}$ Гугнин А. А. Магический реализм в контексте литературы и искусства XX века: феномен и некоторые пути его осмысления. Москва, 1998.117 р. 


\section{Spatial relations in fiction}

The category of space in its relation to fiction is considered to be one of the most relevant in contemporary literary studies. Its theory was developed and formulated by Yu. Lotman ${ }^{6}$, V. Toporov ${ }^{7}$, J. Frank ${ }^{8}$ and others. Lotman distinguished two main approaches in the study of "time and space". The first is related to the Bakhtin's concept of chronotope and involves the study of forms, means and images of artistic transformation of "real" time and space in accordance with the conventions of a particular genre. The second one arises from mathematics, where space is understood as "the set of homogeneous objects (phenomena, states, facts, figures, values of variables, etc.), among which there are relations similar to ordinary spatial relations (continuity, distance, etc.). Therefore, this method requires the approach that views a text as a certain form of space and establishes connections between different elements within the architectonics of a literary text.

After Bakhtin axioms, saturated with exceptionally productive methodological potential, were regarded as the characteristics of a chronotope. They are as follows: 1) a chronotope is comprised only of that what "has become an image in a work", and that what is "created, and does not create"; 2) a chronotope, as well as the genre with which it is most closely associated, is a category of form and content; 3 ) clarification of the points of convergence of real time and space and determination of features peculiar to artistic transformation can define the specificity of a chronotope; 4) a chronotope is revealed through the connection with an image of a person in the literature of a particular period and the analysis of evolution of the genre of the novel through the prism of different types of chronotope testifies this connection.

6 Лотман Ю.М. Проблема художественного пространства в прозе Гоголя Избранные статьи. В 3-х тт. Таллин: Александра, 1993. Т. 1. С. 413-447; Лотман Ю. М. Заметки о художественном пространстве. Избранные статьи. В 3-х тт. Таллинн: Александра, 1992. Т. 1. С 448-463; Лотман Ю. М. К проблеме пространственной семиотики. Ученые записки Тартуского государственного университета. Семиотика пространства и пространство семиотки. Труды по знаковым системам XIX. Тарту, 1986. Вып. 720. С. 3-6.

7 Топоров В. Н. Пространство и текст. Текст : семантика и структура. Москва : Наука, 1983. С. 227-284.

${ }^{8}$ Frank, J. Spatial Form in Modern Literature. Critiques And Essays In Criticism. 19201948. Selected By Robert Wooster Stallman. The Ronald Press Company. New York, 1949. P. 315-328; Frank, J. The Widening Gyre: Crisis and Mastery in Modern Literature. New Brunswick, N.J. : Rutgers University Press. 1963. 278 p.; Frank, J. Spatial Form 30 years after. Spatial Form in Narrative. Ed. by J. R. Smitten and A. Daghistany. Ithaca; London : Cornell University Press, 1981. P. 202-244. 
It should be noted that Bakhtin examined literature in all the stages of its development staring from antiquity to the $19^{\text {th }}$ century inclusive, and its artistic paradigm can be called classical to a certain extent. In this literature, the axiological system of an author and characters, considering a possible complexity of the relationship between them, either had coincided or was clearly separated and understood by the reader. However, since the end of the $19^{\text {th }}$ century a growing segment of literature has been composed of works in which there is a sharp contrast between the values of an author and a character; the narrative is arranged in such a manner that it is difficult for a reader to identify the subject of speech and the latter is devoid of clarity and stability; speech discourse "drifts" from a narrator to a character, images of space and time pertaining to a character are emphatically subjective and cannot be identified as authorial ones. Thus, literature in the first half of the twentieth century certifies the artistic turn from the reproduction of the world of phenomena to the embodiment of the world of entities, and to overcoming deterministic principle of artistic thinking and a mimetic image of reality.

In modernist literature a chronotope undergoes significant changes as well. Works, in which the image of external time and space was problematic, were distributed: it (the image) either did not clearly coincide with real sociohistorical time (like Kafka), or fell out of the "objective" subject representational sphere of a story (like Proust). "External" time and space were replaced by "internal" time and space. A special type of chronotope arose - the chronotope of consciousness, which modified the organization of the principles of an artistic structuring of a work. The linear causal factor lost its structure-forming significance and gaps between text elements arose at different levels, from a story line to a subject, signifying fragmentation as the main principle of modernist narrative.

The new artistic practice required theoretical understanding, and among other methodological categories that were proposed in the first half of the twentieth century, the concept of spatial form proved to be especially productive one. It was proposed in 1945 by the abovementioned American literary critic Joseph Frank in his work "The Spatial Form in Modern Literature". Analyzing the construction of works of T. S. Eliot, E. Pound, M. Proust, J. Joyce, J. Barnes from the point of view of the specificity of their perception by the reader, J. Frank notes that "the reader is intended to apprehend their work spatially, in a moment of time, 
rather than as a sequence" $"$. Thus, the prospects of the special reception of "non-classical" literary text were in the focus of Frank's attention. First, he regarded the poetic works of Eliot and Pound in this context, and then extrapolated the receptive method of innovation comprehending of a poetic form and structure of a new novel. The realignment of the perception process from temporal to spatial is caused by fragmentation of a text, which at the level of image construction is indicated by an increase in the number of associatively linked fragments, and at the level of narrative by a violation of the chronological narrative. This structure of a work complicates the work of a reader. Frank referred to R. P. Blackmore's definition of the Elliot method as "episodic" and pointed to the separation of components of every single episode, the mixing of both verbal and figurative fragments and the constant reversal of narrative. All this required a new way of reading perception, called the "principle of reflexive reference" by Frank $^{10}$. This principle implied an active reader's interpretation of the connections between text fragments devoid of causal logic, but built on the "spatial" logic, as they did not follow each other in the process of storytelling they were connected exclusively by the spatial logic of the whole: |To be properly understood, these word-groups must be juxtaposed with one another and perceived simultaneously; only when this is clone can they be adequately understood; for while they follow one another in time, their meaning does not depend on this temporal relationship| ${ }^{11}$.

J. Frank subsequently returned to his idea in the article "Spatial Form 30 years after" and in view of the experience of formal school, "new criticism", structuralism incorporated the idea of "spatial form" into the wider context of the text theory; at the same time spatial form came to be understood as one of the possible ways of organizing a work of any era, and not just as the dominant principle of organizing a modernist text.

The increase of reader's activity in the process of text perception, the need to compare fragmented elements of the text (episodes, motives, images, text fragments), the non-linearity of reception, the ability to keep in memory certain fragments of events presented considering chronological violations, to compare different points of view, to see the connection between storylines, details, verbal and figurative constructs, intertextual

${ }^{9}$ Frank, J. Spatial Form in Modern Literature. Critiques And Essays In Criticism. 1920-1948. Selected by Robert Wooster Stallman. The Ronald Press Company. New York, 1949. P. 318.

${ }^{10}$ Ibid., p.321.

${ }^{11}$ Ibid. 
references - all this came in the twentieth century as a consequence of the complication of literary technology and brought to life the need for theoretical understanding of an open spatial structure of a text.

The formation of the spatial form was caused by the reorientation of chronotope as a mimetic time and space to the chronotope of consciousness. It is not by chance that in the characterization of modernist works one can often find such expressions as "inner time", "time of consciousness", "heme of memory", "overlay of the past and present in the space of consciousness", etc. Thirty years after J. Frank, in his adjustment of the ideas of spatial form, focused on a significant shift in the parameters of time embodiment in a literary work: "the efforts of stream-ofconsciousness writers such as Joyce, Faulkner, and Virginia Woolf to break up language itself so that it would reproduce the movements of consciousness either on the reflexive or prereflexive level. This effort to depict consciousness is what dramatizes the difference between physical and psychological time, and also calls into question the unity of the self"12.

The assertion of a chronotope of consciousness in twentieth-century literature does not abolish Bakhtin's idea: there is no impassable boundary between his chronotope and Frank's spatial form. Bakhtin always kept in sight the connection of a chronotope with an epoch and its values, and for literature of the epoch of modernism and postmodernism, such a connection should be established as well. Bakhtin wrote about a "special creative chronotope inside which this exchange between work and life occurs, and which constitutes the distinctive life of the work"13, therefore, the world of the work and the world of the author and reader are separated, but the border between them should not be understood as absolute and enduring. "However forcefully the real and the represented world resist fusion, however immutable the present of that categorical boundary line between them, they are nevertheless indissolubly tied up with each other and find themselves in continual mutual interaction; uninterrupted exchange goes on between them, similar to the uninterrupted exchange of matter between living organisms and the environment that surrounds them..."14.

Although Bakhtin did not emphasize the reader's role in the "depicting" world, but the often used phrase "a world of an author-reader"

${ }^{12}$ Frank, J. Spatial Form 30 years after. Spatial Form in Narrative. Ed. by J. R. Smitten and A. Daghistany. Ithaca; London : Cornell University Press, 1981. P. 228.

13 Бахтин М. М. Вопросы литературы и эстетики. Исследования разных лет. Москва : Художественная литература, 1975. С. 403.

${ }^{14}$ Ibid., 402. 
gives the right to say that a reader, as a co-author of the receptive creation of the artistic world, is also connected with the described process of creative interchange. It is at the intersection of the created text and each time re-created by the reader that the concept of spatial form "works". The principle of "reflexive reference" of J. Frank begins to be actualized in the space of meeting the world of a work and the world of an author and reader, when a reader constructs the content of the work from the "pieces", fragments, and compares elements of the text, builds, and draws up a definite artistic whole.

The ideas of $\mathrm{V}$. Toporov regarding the structure of a literary text are also very important. The latter is based on the fact that the text is always spacious i.e. it is a sign of space, located in real space, etc. ${ }^{15}$.

Thus, we can talk about the basic aspects of the study of artistic spatiality problems, they are such as follows: 1) spatiality is the most important property of literary works of any period; 2) artistic spatiality can be interpreted with the help of concepts of "chronotope" ("time and space in the text") and "spatial form" (text space), in the context of which spatiality is understood as a certain system of connections between text elements, on the basis of the time-sequential substitution for spatial simultaneity; 3 ) in the 20th century the predominance of spatial literary forms is connected with the orientation of a creative subject not toward physical but toward psychological time, toward the spatial consciousness of a text construction considering the possibilities of multilevel artistic communication (author - hero - reader); 4) the author's techniques that actualize a spatial organization of the work, create an effect of text fragmentation, "incomplete integrity", "sphere of uncertainty", comprehension of which requires increased reader activity; 5) clarification of a specific character of spatiality in the works with a "complicated" artistic paradigm in the literature of the 20th century creates the necessary prerequisites for an effective interpretation of their semantic versatility.

\section{Transformation of real space and time in Platonov's Universum}

It is unnecessary to prove that Platonov's work was inspired by the dramatic events of his time, which in a specific refraction occupies all the space of the writer's works. The best example of the uniqueness of the Platonov's transformation of real time and space is the novel Chevengur, a kind of author's opus magnum. The spatial and temporal organization of

15 Топоров В. Н. Пространство и текст. Текст : семантика и структура. Москва : Наука, 1983. С. 227. 
the novel is marked by obvious duality: it is, of course, a novel about Russia, about Russian people and Russian society in the era of a radical breakdown of national life; at the same time, it is a novel about human existence, about the eternal and secret, unconditional and incomprehensible in it. The story of the work takes place in a specific historical time-space on the eve of the 1917 revolution and in the post-revolutionary years. However, this fact requires reservations. The events of the "great" story are not included directly in the field of the plot action of the work, but serve only as a background for depicting the wanderings of the characters in search of "the meaning of a separate and common existence."

In Chevengur one can find many real place names associated with the territory of the Voronezh region of Russia, but the spatial and geographical specificity is very relative. In the first part of the novel, published during the writer's life as an independent work (the story The Origin of the Master), there are generally no "links" to a particular topography. In the rest of the text, there is a bizarre mixture of real and invented toponyms, and the latter clearly prevail ${ }^{16}$. The central one is, of course, Chevengur - a geographical name that, in accordance with the "strange" logic of the characters of the novel, acquires interchangeability with the abstract concept of "communism" (comp. Chepurnyi's explanation of the place from where he arrived in the provincial city: "Из коммунизма. Слыхал такой пункт? <..> Пункт есть такой - целый уездный центр. Постарому он назывался Чевенгур"17.

It is significant that Platonov makes his characters fall into spatial "confusion" very often, move in the direction opposite to what they actually need. Let us also pay attention to how and with what speed the characters of the novel overcome distances. So, Sasha Dvanov a few days after a serious wound in the leg all night runs across the steppe to the railway station, first he finds himself in a village, and then in a unfamiliar settlement, at a stand near a certain Fekla Stepanovna. Kopenkin, who is looking for him, passes all the villages that he encounters on his way one after another, checks every yard, and, surprisingly, finds Dvanov soon, although for this he probably would have taken more than one hundred kilometers and spent a lot of time. Characteristic is the very way Kopenkin travels in space; he is always "действовал без плана и маршрута, a

16 See : Ласунский О. Житель родного города. Воронеж, 1999. С. 241-250; Алейников О.Ю. На подступах к «Чевенгуру» (об одном из возможных источников названия). Филологические записки. Вып. 13. Воронеж, 1999. С. 177-184.

${ }^{17}$ Платонов А. П. Чевенгур: [Роман] / Сост., вступ. ст., коммент. Е. А. Яблокова. Москва : Высшая школа, 1991. С. 186. 
наугад и на волю коня" ${ }^{\prime 18}$. Indicative are the attempts of Zakhar Pavlovich to measure the distance to the star ("расставил руки масштабом и мысленно прикладывал этот масштаб к пространству”19) and his concern about the existence of infinity. The sign of the peculiar reversibility of space and time in the novel is a monument to the revolution, the project of which is proposed by Alexander Dvanov: "Лежачая восьмерка означает вечность времени, а стоячая двухконечная стрела - бесконечность пространства..."

The space of Chevengur, being enriched with diverse semantic connotations, is also revealed through the connection of natural and transcendental. This connection is found everywhere in the novel. It is enough to pay attention to the pictures of nature, which Platonov always saturates with metaphysics and intense psychological perception of a man: "За окном, на небе, непохожем на землю, зрели влекущие звезды. Дванов нашел Полярную звезду и подумал, сколько времени ей приходится терпеть свое существование, ему тоже надо еще долго терпеть" $\left.{ }^{21}\right)$. But even such seemingly purely everyday actions as, for example, entering a door and crossing a threshold, looking through a window (mutual transitions between open and closed spaces), are penetrated by transcendental significance ${ }^{22}$.

A particularly important place in the spatial sphere of Chevengur is occupied by motives of the road and movement. Describing the development of the road chronotope in the history of the novel, M.M. Bakhtin emphasizes that the road is "the point of tying and the place of events", it concentrates all the novel conflicts around itself, and most importantly, "the real character's path-road ... insensitively passes into the metaphor of the road, life path, soul path" 23 .

It is easy to see that the road in its literal meaning plays the main plotforming role in Platonov's novel; at the same time, the motive of the path is directly expressed in the structural and compositional organization. In fact, the whole novel is a road to Chevengur, a city that is understood by the characters as a realized idea and a space point in which the past and future cease to exist, are interchanged (see symptomatic replica of one of

${ }^{18}$ Ibid., 119.
${ }^{19}$ Ibid., 53.
${ }^{20}$ Ibid., 144.
${ }^{21}$ Ibid., $99-100$.
${ }^{22}$ See: Дмитровская М.А. Семантика пространственной границы у А. Платонова. Филологические записки: Вып.13. Воронеж, 1999. С. 118-137.

23 Бахтин М. М. Вопросы литературы и эстетики. Исследования разных лет. Москва : Художественная литература, 1975. С. 392-393. 
the characters in the novel: “Деревня, что ль, такая в память будущего есть?..."24). "Идти по земле" 25 is a desire and need not only Zakhar Pavlovich (in connection with the position of which this phrase appears in the text), but almost of all the characters of the novel: Sasha Dvanov, Kopenkin, Gopner. In the city of Chevengur there is even a "regular pedestrian" Luy, who believes that “коммунизм должен быть непрерывным движением людей в даль земли"; he is convinced that it is the "joy of movement" that is a kind of primary source and the main factor of all overcoming in the world (with all the paradoxes and even absurdities of the character's logic, his 'discoveries' are very attractive, for example: “отчего летит камень: потому что он от радости движения делается легче воздуха",26).

But not only the "real" road is significant in Chevengur. In the motive of the path, Platonov reveals a whole complex of metaphorical meanings. The most important thing is the "life way", the spiritual movement, the development of the characters.

Such a conditionally symbolic meaning "road-way" acquired in ancient times, which is embodied in the mythological models of the world among various nations. A known researcher of archaics and mythopoetics V. Toporov points out that "in many mythological and religious traditions, the mythologem of the way appears metaphorically, as a designation of a line of behavior (especially often moral, spiritual), as a set of rules, law, and doctrine" 27 .

In the artistic and aesthetic sense, the concepts of "road" and "way", being closely interconnected, still differ. Yu. Lotman notes on this: "Road" is a certain type of art space, "way" is the movement of a literary character in this space. The "way" is the realization (full or incomplete) or the unrealization of the "road" 28 . Further, Yu. Lotman emphasizes that "with the advent of the image of the road as a form of space the idea of the way is formed as a norm of human life, peoples, humanity. Characters are sharply divided into moving (characters of the way) and motionless"29.

The idea of the way in Chevengur is most fully embodied by Alexander Dvanov - a key character, is regarded as the embodiment of author's ideas

${ }^{24}$ Платонов А. П. Чевенгур..., 186.

${ }^{25}$ Ibid., 30.

${ }^{26}$ Ibid., 218.

${ }^{27}$ Топоров В. Н. Путь. Мифы народов мира. Энциклопедия. В 2-х т. Москва : Сов. энциклопедия, 1980. Т.2. К-Я. С. 353.

28 Лотман Ю.М. Проблема художественного пространства в прозе Гоголя. Избранные статьи. В 3-х тт. - Таллин : Александра, 1993. Т. 1. С. 413-447.

${ }^{29}$ Ibid., 446. 
in the novel. His image symbolizes the very process of becoming a person along the way. The road/way acquired significance already in the childhood of the hero. He, as a "rootless orphan", a "parasite" who has taken root in alien house, is sent with a pauper scrip to beg in the city. The narrative emphasizes the moment of access to the road and the description of the road itself: "Прохор Абрамович наклонился к сироте. - Саша, ты погляди туда. Вон, видишь, дорога из деревни на гору пошла - ты все так иди и иди по ней"30. "Дорога из деревни на гору" - this is the way that V. Toporov calls the most important kind of mythologem of the way, the way from home "to the strange and terrible periphery" 31 . In the psychological perception of the boy himself, the road becomes a sign of "strange and terrible": "На высоте перелома дороги на ту, невидимую, сторону поля мальчик остановился. В рассвете будущего дня, на черте сельского горизонта, он стоял над кажущимся глубоким провалом, на берегу небесного озера. Саша испуганно глядел в пустоту степи; высота, даль, мертвая земля - были влажными и большими, поэтому все казалось чужим и страшным..."32.

However, gradually the movement to the "periphery" turns for the protagonist of the novel into the second kind of path mythology - the movement to the sacred center, "when the highest good is acquired by gradually approaching it" ${ }^{\prime 3}$. The city of Chevengur, where Sasha Dvanov goes, is an idea city, a city of "communism" (see above on the identification of the city and communism). Along this path, Alexander Dvanov has to overcome a lot of difficulties, and this is very symptomatic, since "the difficulty of the path is a constant and inalienable property, to move along the path, to overcome it is already a feat, asceticism from the side of a moving ascetic, traveler" 34 .

There is a train wreck, dreams about the road, a fatal wound, and a serious illness (it lasts, by the way, nine months and ends with a new exit onto the road, which is accompanied by significant commentary by the narrator: “Жизнь снова заблестела перед Двановым...”35). Overcoming all these "difficulties" can very well be assessed as the character's initiation - the assertion of his high mission, which was revealed to him in

\footnotetext{
${ }^{30}$ Платонов А. П. Чевенгур..., 42.

31 Топоров... С. 352.

32 Платонов А. П. Чевенгур..., 43-44.

${ }^{33}$ Топоров..., 352.

${ }^{34}$ Ibid.

${ }^{35}$ Платонов А. П. Чевенгур..., 90.
} 
a dream in conversation with his father when he tells his son: “Делай чтонибудь в Чевенгуре: зачем же мы будем мертвыми лежать...”,

The goal - "city-communism" - to which Alexander Dvanov takes so long and hard, is deprived of analogues in the world and contrasted with the whole "other" world in its spatial and temporal dimensions. "Какой тебе путь, когда мы дошли...", “история кончилась"37, - in these significant expressions of the Chevengur leader Chepurnyi, there is a complete stop in the "city-communism" of any movement - in its direct and figurative meaning. In such a quality - as the end of the road, the antithesis of the movement - Chevengur, of course, must perish. But even before the immediate destruction of the Chevengur utopia, its organizers, in fact, themselves abandon this embodied idea. Having created a city closed in itself, stopped in space and time, they, as it turns out, are not able to live without movement. There comes a time when each of the adherents of "ultimate happiness" "gets tired of standing" and is about to set off again. The above-mentioned Luy, the staunchest proponent of "walking", offers Chepurnyi, “чтобы тот объявил коммунизм странствием и снял

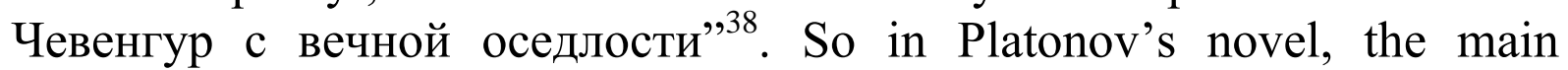
passion of the Russian soul declares itself - the attraction to pilgrimage. Ultimately, it is movement and open space that remain the last refuge of Russian people. Truly in this novel the most convincing confirmation is the idea that "Russia is carried out as an endless dialogue between St. Petersburg and Russia, the city and the road. Read the "gorod" on the contrary - the "doroga" will come out: they are antipodes. Petersburg is a "place", a point, and Russia is a path-road"39.

As we see, the space in Platonov's novel appears not just as a territory for the unfolding of an action, but turns into a universal category, forming a special kind of existential phenomenon. The uncertainty of the spatial spheres, the lack of topographic accuracy, the confusion of man in space, obviously, are aimed at emphasizing the vagueness and uncertainty of a person's position in the world, his existential "abandonment" (S. Kierkegaard), the loss of meaning and purpose of existence, and the feeling of painful impossibility to escape beyond the empirical world.

\footnotetext{
${ }^{36}$ Ibid., 241.

${ }^{37}$ Ibid., 315.

${ }^{38}$ Ibid., 218.

39 Гачев Г. Д. Национальные образы мира. Москва : Советский писатель, 1988.
} C. 386 . 


\section{The space of text in a Platonov's fiction}

Now let's take a look at what Platonov's prose is from the point of view of "space of text", again on the example of the novel Chevengur. We will take into account how the idea of spatial form is realized at different levels of the poetics of the novel: in the plot-composition structure, in architectonics, in the structure of characters, in the isomorphism of architectonic form and syntactics of linguistic units. In relation to the plot action, Chevengur is characterized by discreteness and "randomness" of events; there are many "independent" episodes and characters in the novel, that are loosely interconnected. Many of them generally fall out of the main plot (such as the situation with the teacher Nekhvoraiko or the impoverished Firs). In their sequence, individual episodes of the novel do not explain the previous ones and do not eventually prepare the subsequent ones. The non-causal nature of the development of the action is exacerbated by the absence of external eventual conflict tension, and the author's detachment gives the impression of disconnectedness and fragmentation of the episodes, uncontrolled development of the plot, its free "self-creation".

Trying to retell the plot (more precisely, the plot, in accordance with the distinction of these concepts in the traditions of the formal school), or even doing page-by-page commenting "after the author", as Ye. Yablokov does, we can conclude that the plot structure has a fairly traditional look linear time-based deployment with sequentially strung episodes. In Chevengur, these are the movements of Alexander Dvanov and Kopenkin "across Russia" in search of "amateur communism". But in this case, we draw a zigzag, recursive plot of the work into a straight line. In fact, the line of direct movement all the time tries to turn into movement in a circle, returning to the same points closer to the center of this circle, for example, father's death for Alexander Dvanov or Kopenkin's tendency towards Rosa Luxemburg.

It is important to note the characteristic changes that the text architectonics undergo as the story unfolds. At first, it gravitates towards realistic aesthetics (part 1). In any case, there is still no cardinal break with realistic tradition, although the potential for overcoming it is considerable, it's enough to recall the scenes of the death of children on the first pages of Chevengur. However, gradually the properties of the classical text in the novel are lost. Strange and unusual actions, already set by the first phrases of the novel, develop into "non-fantastic fantasy" (Yu. Mann), built on the principles of a dream vissions or a game of imagination.

The originality of the plot correlates with the overall architectonics of the work. Platonov does not divide the text into chapters and sections, 
although he creates special gaps in it, the purpose of which, apparently, is to direct reading in a certain way. Episodes are simply strung in chronological order one on top of another, without claiming to be some kind of "special" organization, i.e. they form so-called cumulative structure, which is recognized by many researchers of modernist prose as one of its most significant features ${ }^{40}$.

As for the internal, deep linkages of the text, the structuring of material is carried out mainly on the basis of motive connections and parallels. A vivid example of motivness as a structural-organizing principle of the text is the implementation the death motive as a special "return" to the original source of life in a number of episodes of the novel: the death of a train driver, the death of an unnamed Red Army soldier after a train crash, the death of a merchant Schapov, and the Sasha Dvanov's immersion in the waters of Lake Mutevo.

Another important aspect concerns the correlation of the classical and modern versions of the spatial text is the structure of the character's. In a realistic novel, it is determined by a fairly stable scheme: the actions of the heroes and their motivation by the narrator and by the heroes themselves; biography and appearance; interior and landscape; "explicit" and "secret" psychologization (L. Ginzburg), etc. In modernist literature, this scheme is largely losing its significance. The sharp changes in characterology were caused, first of all, by the concept of personality, which is reflected in one way or another in a wide variety of works correlated with the phenomenon of modernism. Its essence in the most general form is expressed by the Joyce's formula from Ulysses: «Everyman or Noman». In another novel by Joyce - Finnegans Wake - the most important leitmotif associated with the image of the Common Man is conveyed by the acronym HCE, which can be decrypted in different ways (Here Comes Everybody or Haveth Children Everywhere), but the meaning of which in any case comes down to the idea of depersonalization of the personality, supremacy of universal archetypal qualities. ${ }^{41}$.

Like other modernist works, Chevengur is very far from traditional fictional characterology. The biographical data of the characters of the novel are extremely scarce; their appearance, as a rule, comes down to one or two details; the inner world, if it is revealed, is basically without the analytic penetration of the narrator into it. The connection at the level of

40 See, for example: Федоров В. В. Кумулятивный принцип сюжетостроения в неклассической поэтике : Дисс. ... канд. филол. наук.. Тверь, 2011. 172 с.

${ }^{41}$ See: Корнуэлл Н. Дж. Джойс и Россия. - Санкт-Петербург : «Акакдемический проект, 1997. С. 51, 57. 
"character - plot" is already indicative. The participation of the characters in the development of the action is minimized (in the sense that plot is not driven by causal patterns of their actions, but mainly by the will of the author, who freely combines events and spatio-temporal plans of the narrative). Moreover, the motivation for the actions of characters is extremely reduced or clearly illogical. It is enough to recall the "voluntary" death of Alexander Dvanov's father, who "думал все об одном и том же - об интересе смерти" and drowned in the lake because "хотел посмотреть - что там есть: может быть, гораздо интересней, чем жить в селе или на берегу озера; он видел смерть как другую губернию, которая расположена под небом, будто на дне прохладной воды, - и она его влекла" ${ }^{\text {"42 }}$, or actions of the Chevengurs when they dump a tank with a singing woman inside it into a ravine, etc.

Of particular interest in the field of character poetics in Chevengur are the features of the disclosure of the human inner world. It seems that Platonov completely refuses such traditional means of psychologization as an internal monologue, free indirect speech. His attention is attracted by a special psychological phenomenon - the "elementary nature" of human psychology. It is known that from the end of the 19th century a whole branch of "elementary" psychology developed (in another way, empirical, that is, proceeding from the idea of the predetermination of the human psyche by concrete sensory experience). In Chevengur we are facing fact that the inner world of characters appears as something like a "conglomerate" of psychic elements (compare about Chepurnyi: "в голове его, как в тихом озере, плавали обломки когда-то виденного мира и встреченных событий, но никогда в одно целое эти обломки не слеплялись, не имея для Чепурного ни связи, ни живого смысла...”, ${ }^{43}$. The form of expression of such a phenomenon in the novel is not the narratological features of the style, but the actual speech sphere of the characters and the author (as close as possible to them). This is manifested in the consistent linguistic embodiment of the Platonov's idea that there is nothing in the human mind that would not be in his sensations. Accordingly, the characters' speech contains only what is present in their sensory perception of the environment and even imagined by them. Hence the following "strange" phrases in the speech of the narrator and characters

\footnotetext{
${ }^{42}$ Платонов А. П. Чевенгур..., 28.

${ }^{43}$ Ibid., 206.
} 
of the novel: “слушал внимательным умом"44; “со своим слушающим чувством"45; “"зорко вспоминала всю жизнь” 46 .

The inner world of the characters, seen by the author who is "inside the depicted consciousness" (L. Shubin), is devoid of linearity, it constantly gravitates toward diverse, "fan-shaped" branching and actualizes the need for perception not of the temporal (that is, sequential and causal), but of the spatial (that is, simultaneous and integral).

The language form of the novel is also organized in such way. Platonov's language style itself is a huge research problem, so we will focus exclusively on some principles of the correlation between language elements and the text as a whole, in particular, on the isomorphism of the syntax and architectonics of the novel. In an interesting study by E. Rudakovskaya, the most important features of the syntax of Platonov's sentence were identified: "an abundance of polynomials, union-free sentences in which simple ones are connected by indirect connection, authorization, repetitions, parallelisms of constructions, uneven logical structuring of the reported material, multicomponent complication, syntactic homonymy, convergence..." $"$. This structure of syntax corresponds to the general architectonic construction of the novel, in which there is no division into separate structural parts, and to the movement of the novel plot, built, as was noted above, in accordance with the cumulative principle. This allows us to discover new shades of the artistic philosophy of the novel in each new episode and in every overtone of the linguistic system, while permanently correcting the author's position and the reader's perception.

Thus, at different levels of the artistic structure of A. Platonov's novel "Chevengur", a specific correlation of textual elements is traced based on non-causal connections and the replacement of sequence in time by simultaneity in space. This allows us to see in this work one of the brightest examples of spatial form in the literature of the twentieth century.

\section{CONCLUSIONS}

The analyses of A. Platonov's prose in the light of spatial theory in literature allow us to draw the following conclusions. There are two different aspects of spatiality in Platonov's fiction: "space of life" (the

\footnotetext{
${ }^{44}$ Ibid., 243.

${ }^{45}$ Ibid., 248.

${ }^{46}$ Ibid., 299.

${ }^{47}$ Рудаковская Э. Роман Андрея Платонова «Чевенгур»: синтаксис предложения и построение текста Русская филология. Тарту, 1996. № 7. С. 230.
} 
relation between real socio-historical space and fictional one), and "space of text" (specific language of modeling of a text and a system of relations between textual elements based on substitution of sequence in time on simultaneity in space).

"Space of life" in Platonov's works is closely connected with the dramatic events of his time, which in a specific refraction occupy all the space of the writer's works. The best example of the uniqueness of the Platonov's transformation of real time and space is the novel Chevengur. The plot of the novel takes place in a specific historical time-space on the eve of the 1917 revolution and in the post-revolutionary years. However, the events of the "great" story are not included directly in the field of the plot action of the work, but serve only as a background for depicting the wanderings of characters in search of "the meaning of a separate and common existence". The uncertainty of the spatial spheres, the lack of topographic accuracy, the confusion of man in space are aimed at emphasizing the vagueness and uncertainty of a person's position in the world, his/her existential "abandonment", the loss of the meaning and the purpose of existence, and the feeling of painful impossibility to from the empirical world.

Consideration of Platonov's Chevengur from the point of view of "space of text" shows that all elements of the novel's artistic structure correlate with the concept of spatial form. The plot of the novel is marked by discretion; there are many "independent", loosely connected episodes and characters. In their sequence, individual episodes of the novel do not explain the preceding and do not prepare? the subsequent ones. The noncausal nature of the development of action is exacerbated by the absence of exotic conflict tension, and authorial detachment creates the impression of disunity and fragmentation of episodes, lack of control in the plot development, its free "self-assertion". The narrative model of the novel is determined by the rejection of the omniscient author. The "obscurity" of the narrator's position correlates with the "wandering" point of view, when the author allows co-existence of the opposing views in the text. This method is extended to the actual narrative "points of view" (focuses of the vision), extremely mobile and mutually interdependent.

\section{SUMMARY}

The article deals with the problem of spatiality in A. Platonov's fiction. The author interprets spatiality in two characteristics: as a specificity of a transformation of real time and space and as a specific language of modeling of a text and a system of relations between textual elements based on substitution of sequence in time on simultaneity in space. Both of 
these aspects reflect Platonov's attempts to create an amalgamation of social, ideological, national, archaic and modern approaches in resolving the problem of human existence. The writer focuses uncertainty on the spatial spheres and the confusion of a man in space emphasizes the vagueness and uncertainty of a person's position in the world. Different levels of the artistic structure of Platonov's novel Chevengur demonstrate a specific correlation of textual elements is traced based on non-causal connections and the replacement of sequence in time by simultaneity in space. This allows us to see in Platonov's work one of the brightest examples of spatial form in the literature of the twentieth century.

\section{REFERENCES}

1. Бахтин М. М. Вопросы литературы и эстетики. Исследования разных лет. Москва : Художественная литература, 1975. 504 с.

2. Гачев Г. Д. Национальные образы мира. Москва: Советский писатель, 1988.445 с.

3. Гугнин А. А. Магический реализм в контексте литературы и искусства XX века: феномен и некоторые пути его осмысления. Москва, 1998. 117 с.

4. Замятин Д. Н. Империя пространства: географические образы в романе А. Платонова «Чевенгур». Филологические науки. 2000. № 1. C. 14-23.

5. Левин Ю. От синтаксиса к смыслу и далее («Котлован» А. Платонова). Семиотика и информатика. Вып. 30. Москва, 1990. C. 115-148.

6. Лотман Ю. М. Заметки о художественном пространстве. Избранные статьи. В 3-х тт. - Таллинн : Александра, 1992. Т. 1. C. $448-463$.

7. Лотман Ю. М. Структура художественного текста. Об искусстве. Санкт-Петербург : «Искусство - СПБ», 1998. С. 14-285.

8. Лотман Ю. М. К проблеме пространственной семиотики. Ученые записки Тартуского государственного университета. Семиотика пространства и пространство семиотики. Труды по знаковым системам XIX. Тарту, 1986. Вып. 720. С. 3-6.

9. Лотман Ю. М. Проблема художественного пространства в прозе Гоголя. Избранные статьи. В 3-х тт. Таллин : Александра, 1993. Т. 1. C. 413-447.

10. Платонов А. П. Чевенгур: [Роман] / Сост., вступ. ст., коммент. Е. А. Яблокова. Москва : Высшая школа, 1991. 654 с. 
11. Подорога В. Евнух души. Позиция чтения и мир Платонова. Параллели (Россия - Восток - Запад). Альманах философской компаративистики. Вып. 2. Москва, 1991. С. 33-82.

12. Рудаковская Э. Роман Андрея Платонова «Чевенгур»: синтаксис предложения и построение текста Русская филология. Тарту, 1996. № 7. С. 226-235.

13. Топоров В.Н. Пространство и текст. Текст : семантика и структура. Москва : Наука, 1983. С. 227-284.

14. Топоров В.Н. Путь. Мифы народов мира. Энциклопедия. В 2-х т. Москва : Советская энциклопедия, 1980. Т. 2. К-Я. С. 352-353.

15. Яблоков Е.А. На берегу неба (роман Андрея Платонова «Чевенгур»). Санкт-Петербург : Изд-во «Буланин», 2001. 376 с.

16. Frank, J. Spatial Form 30 years after. Spatial Form in Narrative. Ed. by J. R. Smitten and A. Daghistany. Ithaca; London : Cornell University Press, 1981. P. 202-244.

17. Frank, J. Spatial Form in Modern Literature. Critiques And Essays In Criticism. 1920-1948. Selected By Robert Wooster Stallman. The Ronald Press Company. New York, 1949. P. 315-328.

18. Frank, J. The Widening Gyre: Crisis and Mastery in Modern Literature. New Brunswick, N.J. : Rutgers University Press. 1963. 278 p.

\section{Information about the author:} Keba O. V.

Doctor of Philological Sciences, Professor at the Department of Foreign Languages, Kamianets-Podilskyi National Ivan Ohiienko University 61, Ivan Ohiienko str., Kamianets-Podilskyi, 32302, Ukraine 